Conditions of Rational Inquiry

A Study in the Philosophy of Value. By David Pole. Pp. ix +229 . (London: The Athlone Press, University of London, 1961. Distributed by Constable and Co., Ltd.) $30 s$. net.

FROM his previous book, wo have come to regard 4 Dr. David Pole as an able commentator on Wittgenstein. Now ho has produced a larger work, having contacts with his earlier themo, but sotting forth, as it were, a contemporary approach to the ever-present problems of value. With one or two notablo exceptions, Great Britain has not been to the fore in discussions of axiology, and this fact makes the volume before us all the more welcome. The author begins with a critique of intuition, and follows this up by considering the concept of decision, the process of inquiry, the development of judgment, knowledge of principles, theory and conduct, and the form of moral concepts. For the scientist of to-day, these matters have great significance. Some current philosophy tends to take a subjective view in that principles depend on personal choice (one might almost say upon porsonal predilections), whereas evaluation is essential if we are to reach a position of rational inquiry.

Whether this could come about by using the structure of normal language alone is hard to say. Leibniz might have doubted it, and so might those (and they carry much weight) who see the future of ethics bound up with the advance of symbolic logic. But the strength of tho author's text lies in its appeal to human situations, and the way in which we react to them when personal conduct is involved. It is just that which makes the last chapter so illuminating: both nations and individuals need to learn more than ever before how to distinguish specifically between honour as something to be upheld as such, and when victory can be gained because "she stoops to conquer". F. I. G. RawLINS

\section{Handbook of Thermophysical Properties of Solid} Materials.

By Alexander Goldsmith, Thomas E. Waterman and Harry J. Hirschhorn. Vol. 1: Elements (Melting Temperature Above $1000^{\circ}$ F.). Revised edition. Pp. vi + 758. (London and New York: Pergamon Press, 1961.) $£ 33$ per set of five volumes.

THIS volume comprises nearly eight hundred loose-leaf sheets of thermophysical property data prepared by the Heat Transfer Section of the Fluid Dynamics and Systems Research Division of the Armour Research Foundation, covering work carried out during 1940-57. Subsequent volumes will deal with alloys, ceramics and cermets, intermetallics, polymerics and composites. The object of the study is the practical one of providing a readily available sourco of data on materials which may find. application in the design of propulsion systems, nuclear power plants, space-vehicles and so on. The volume contains a brief materials index, which is really a classification of all the high-temperature materials, under eleven headings, followed by tablos of conversion factors, and then the great bulk of the material consists of a number of data shects about each of the clements concerned, arranged in alphabetical order. All the different forms in which carbon is available, evon including lamp black, are all classified after carbon, but have different titles, according to their actual names. Aluminium, as one of the well-studied olements, has, for example
18 pages of data, including detailed graphs of the actual experimental measurements as a function of temperature of such properties as specific heat. thermal conductivity, spectral and overall emissivity. linear thermal expansion, vapour pressure, electric resistivity. There is no doubt that the provision of a detailed set of data sheets of this type provides a very convenient way of obtaining ready reference to a vast mass of data, and the book is undoubtedly useful as an encyclopædic reference document, and it can be kept up to date by means of the loose-loef principle.

M. W. Thring

Flora of the Santa Cruz Mountains of California A Manual of the Vascular Plants. By John Hunter Thomas. Pp. vi +434. (Stanford, Calif.: Stanford University Press; London: Oxford University Press, 1961.) 68s. not.

CALIFORNIA has been fortunate in having over the past century a number of resident botanists on whose records at least three authoritative descriptive Floras of the State have been based. The Santa Cruz Mountains in central California, which are of course comprehended in the larger regional works, form a distinct geographical and phytogeographical unit with a rich vascular flora. This natural enclave is highly populated, and the vegetation has been profoundly altered by man in the course of throe centuries so that of the 1,800 recorded species representative of 167 families about 30 per cent have been introduced mainly from Eurasian or North African sources and only a small fraction ( $I .5$ per cent) are endemics. Preliminary discursive chapters deal with the geology of the area, its elimate and the various ecological communities. There is also a discussion on the composition of the flora and the distribution of its constituents within and beyond the Santa Cruz Mountains and a plea is made that the publication of this work will encourage conservation measures to protect threatened mountains, forests, beaches and grasslands. A brief account of the history of botanical collecting in the region completes the introduction.

The treatment of the flora is remarkably comprehensive with excellent keys to the major plant groups, families, genera and species. Identification is further assisted by a judicious selection of 250 line drawings. This well-produced work, most attractive in its format and typography, will be a welcome instrument to beginners or trained botanists interested in the flora of this attractive part of California.

Grorge TAYLOR

\section{Elements of Solid State Theory}

By Dr. Gregory H. Wannier. Pp. vii +270 . (Cambridge: At the University Press, 1959.) 35s. not.

THE author states in his proface that this book 1 was intendod to be one which could be read from cover to cover by non-specialists wishing to understand some, but not all, of the main ideas spocific to solid-state physics. It succeods admirably, leaving relatively fow topics of present-day interest untreated-tho most important, porhaps, being dislocation theory and superconductivity. Magnetism also gets rathor less than its due. The book will be useful, also, as supplemontary reading for final yoar honours students, and as refreshment for spocialists. There are extromely useful problems after each chapter, and good references and suggestions for furthor roading.
G. O. JoNes 